\title{
Pengaruh perbedaan pancing jigs beradium dan berlampu terhadap hasil tangkapan sotong di perairan pantai Sario Tumpaan Kota Manado
}

\author{
Effect of radium- and light-attached jigs on cuttlefish catch in the coastal waters of \\ Sario Tumpaan, Manado City
}

\author{
SitTI MARYAM, ElOF M. KATIANDAGHO* dan ISROJATY J. PARANSA
}

Program Studi Pemanfaatan Sumberdaya Perikanan, Fakultas Perikanan dan Ilmu Kelautan, Universitas Sam Ratulangi, Manado 95115

\begin{abstract}
There are many techniques have been used to increase the fishing power of jigs, such as the use of jigs' shape and color imitating the prey and the use of radium and blinking lights attaching to the jigs. The scientific information of their applications, however, is unavailable. This research was designed to study the effect of the use of radium and blinking lights on cuttlefish catch, and to identify all catch and environmental factors influencing jigs operations. Catch data were analyzed using t-test, to compare the mean of jigs treatment. During the experiment, the total catch is 50 cuttlefish with 33 cuttlefish caught with radium-attached jigs and 17 cuttlefish caught with blinking-lightattached jigs, and all the cuttlefish are of Sepioteuthis lessoniana. Several main environment factors affecting the jigs operations are currents, waves and winds.
\end{abstract}

Keywords: fishing-rod jigs, cuttlefish

\begin{abstract}
ABSTRAK
Banyak cara yang telah digunakan untuk meningkatkan fishing power dari pancing jigs, seperti bentuk dan corak warna yang menyerupai makanan alami, penggunaan radium pada beberapa bagian tubuh pancing dan lampu berkedip. Tetapi informasi ilmiah tentang aplikasinya belum tersedia. Penelitian ini bertujuan untuk mempelajari pengaruh perbedaan pancing jigs beradium dan berlampu terhadap hasil tangkapan sotong dan juga untuk mengidentifikasi hasil tangkapan dan faktor-faktor lingkungan yang mempengaruhi pengoperasian pancing jigs.

Data tangkapan dianalisis dengan uji-t, yaitu perbandingan nilai tengah. Hasil tangkapan yang diperoleh selama pengoperasian pancing jigs adalah berjumlah 50, dimana 33 ekor tertangkap dengan pancing jigs beradium dan 17 ekor lainnya tertangkap dengan pancing jigs berlampu, dan semuanya dari jenis Sepioteuthis lessoniana. Faktor lingkungan utama yang mempengaruhi pengoperasian pancing jigs antara lain adalah arus, gelombang dan angin.
\end{abstract}

Kata-kata kunci: pancing jigs, sotong

\section{PENDAHULUAN}

Salah satu sumberdaya perikanan yang sudah dikenal ekonomis penting adalah dari kelas Chepalopoda yang jenisnya terdiri dari cumi-cumi (squid), sotong (cuttlefish) dan gurita (octopus), tetapi masyarakat lokal sering menyebut squid dengan cuttlefish sebagai cumi-cumi atau suntung. Penangkapan cumi-cumi dan sotong oleh nelayan di perairan Sulawesi Utara biasanya menggunakan

\footnotetext{
*Penulis untuk penyuratan; e-mail: elofmk@yahoo.co.id
}

teknik memancing secara horizontal atau squidtrolling (Saranga, 2009); akan tetapi teknik penangkapannya masih bersifat tradisional dengan cara menarik alat tangkap di belakang perahu sambil mendayung.

Pemanfaatan sumberdaya sotong selama ini masih bertumpu pada alat tangkap pancing jigs, menggunakan umpan buatan yang meniru bentuk udang, baik buatan sendiri oleh nelayan, maupun yang dibuat dalam pabrik. Jigs merupakan alat pancing yang dikhususkan untuk menangkap 
cumi-cumi atau sotong, berbentuk udang, ikan atau bentuk lainnya dengan mata pancing banyak pada bagian ekor tetapi tidak mempunyai kait balik atau barb (Rakian, 2011).

Banyak cara yang telah digunakan untuk meningkatkan fishing power dari pancing jigs, seperti bentuk dan corak warna yang menyerupai makanan alami, penggunaan radium pada beberapa bagian tubuh pancing dan lampu berkedip; yang fungsinya untuk lebih menarik perhatian sotong sehingga menyerang pancing dan tertangkap, tetapi informasi ilmiah tentang aplikasinya belum tersedia.

(a)

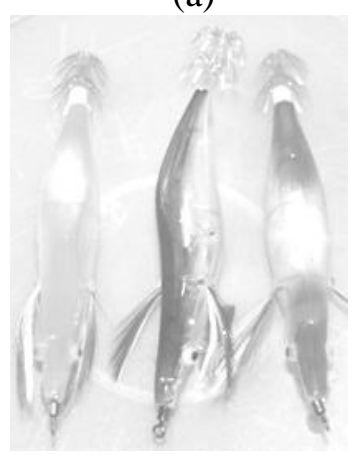

Gambar 1. Pancing jigs dengan cahaya lampu battery (a) dan cahaya radium (b)

Di lain pihak, belum diketahui secara ilmiah apakah umpan sotong yang beradium lebih efektif dibandingkan dengan yang berlampu. Oleh karena itu dipandang perlu untuk melakukan penelitian pengaruh material pancing yang beradium dan berlampu terhadap hasil tangkapan sotong (Sepia sp.)

Kata Cephalopoda, dalam bahasa Latin terdiri dari dua kata chepale: kepala, dan podos: kaki, yang artinya berkaki di kepala. Kelas Chepalopoda ini dibagi dalam empat golongan besar yaitu cumi-cumi, sotong, gurita, dan suen chiu (argonauta). Cumi-cumi memiliki 10 tentakel yang terdiri dari 2 tentakel panjang dan 8 tentakel yang lebih pendek (Nontji, 2000).

Kelas Cephalopoda adalah kelompok tertinggi tingkat evolusinya di antara Phylum Mollusca. Tubuh simetri bilateral, dan sistem saraf yang berkembang baik terpusatkan di kepala. Mereka mempunyai pandangan mata yang sangat bagus, berenang dengan cepat, menunjukkan emosi, berubah warna dengan cepat menggunakan kromatofor, dan dapat merayap di dasar atau berenang di dasar perairan. Sotong, dapat dibagi atas dua jenis yaitu sotong batu dan sotong buluh. Sotong batu termasuk dalam kelompok sepia yang mempunyai tulang punggung yang keras, sering disebut batok sotong (cuttlebone). Sedangkan sotong buluh termasuk Sepioteuthis, yang mempunyai batok agak lunak, bentuknya seperti plastik dan sering disebut pens (Hamzah dan Sutomo, 1992).
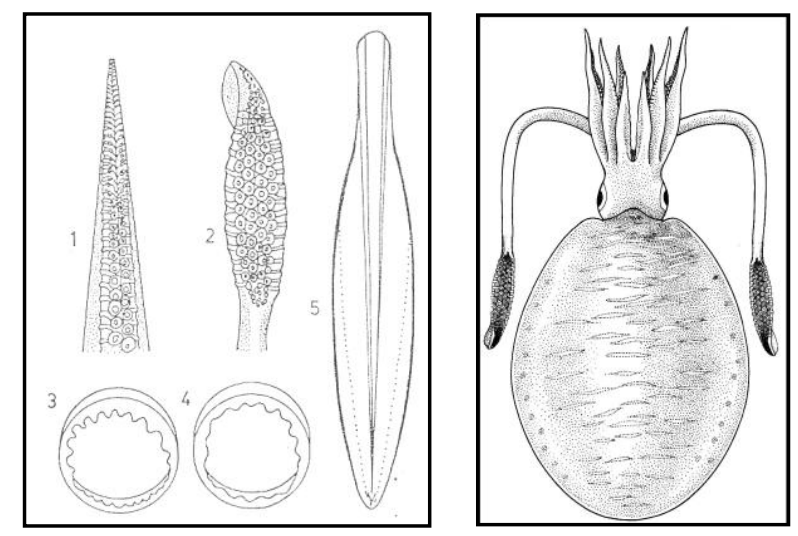

Keterangan gambar :

1. Lengan / jari-jari kiri IV pada hectocotylize

2. Kelompok tentakel

3. Cincin pengisap pada lengan/jari-jari III

4. Cincin pengisap pada kelompok tentakel

5. Batok sotong (pens)

6. Bentuk punggung sotong jenis Sepioteuthis lessoniana

Gambar 2. Morfologi sotong

\section{METODOLOGI PENELITIAN}

Penelitian ini dikerjakan dengan mengikuti metode eksperimental, yaitu suatu rancangan percobaan yang diujicobakan untuk memperoleh informasi tentang persoalan yang sedang diteliti. Dengan metode ini dapat diperoleh informasi yang diperlukan dalam melakukan penelitian tentang persoalan yang akan dibahas sehingga akan dihasilkan suatu kesimpulan sesuai dengan tujuan penelitian (Sudjana, 1994). Asumsi-asumsi yang menyertai penelitian ini adalah:

(1) Sotong yang ada di perairan pantai Kelurahan Sario Tumpaan mempunyai peluang yang sama untuk tertangkap denganpancing jigs beradium dan pancing jigs berlampu.

(2) Para pemancing mempunyai ketrampilan yang sama mengoperasikan alat tangkap pancing jigs. 


\section{HASIL DAN PEMBAHASAN}

Hasil tangkapan yang diperoleh selama pengoperasian pancing jigs adalah berjumlah 50, dimana 33 ekor tertangkap dengan pancing jigs beradium dan 17 ekor lainnya tertangkap dengan pancing jigs berlampu, dan semuanya dari jenis Sepioteuthis lessoniana. Hasil analisis menunjukkan bahwa t-hitung $=2,667>\mathrm{t}$-tabel $\mathrm{t}_{0,05 ; 8}$ = 2,306; sehingga menolak $\mathrm{H}_{0}$ dan menerima $\mathrm{H}_{1}$, dimana hal ini ini menjelaskan bahwa rata-rata yang menggunakan pancing jigs beradium berbeda dari rata-rata yanng menggunakan pancing jigs berlampu terhadap hasil tangkapan sotong pada tingkat kepercayaan $95 \%$.

Semua sotong hasil tangkapan terdiri dari jenis Sepioteuthis lessoniana; sama seperti yang dilaporkan oleh Rakian (2011), menggunakan jigs yang ditarik di belakang perahu saat bulan terang pada daerah penangkapan yang juga sama. Faktor lingkungan utama yang mempengaruhi pengoperasian pancing jigs antara lain adalah arus, gelombang dan angin. Arus yang kuat dapat menyebabkan pancing jigs terangkat ke arah permukaan, dan jika tali pancing diulur terus akan menyebabkan pancing jigs tersangkut pada batu karang. Nampaknya sotong tidak bernafsu menyambar pancing jigs ketika berarus kuat, dan kemungkinan sotong berlindung diantara batubatuan untuk menghemat energi agar tidak terbawa arus. Gelombang yang besar menyulitkan pengoperasian pancing jigs karena posisi pemancing kadang-kadang tidak stabil di atas perahu, dan gerakan pancing jigs tidak mampu menarik perhatian sotong. Angin yang kuat dapat menimbulkan gelombang dan menyeret jangkar perahu ke perairan yang lebih dalam.

Berdasarkan jumlah total hasil tangkapan sotong pada masing-masing perlakuan menunjukkan bahwa pancing jig yang beradium lebih efektif dari pancing jigs berlampu kedip dari tenaga battery.

Pengamatan lapang memperlihatkan bahwa pancing jigs beradium mengeluarkan cahaya yang lebih alamiah mirip mangsa sotong; atau mirip warna atau cahaya yang dikeluarkan sotong saat berkomunikasi di antara sesamanya. Cahaya pancing jigs berlampu nampaknya terlalu kuat, dan kedipan lampu membuat sotong agak curiga untuk menyambarnya.

Kadang-kadang sotong pada awalnya tertarik lampu jigs dari jarak jauh, kemudian mendekati dan menyelidikinya, tetapi lebih cenderung memilih menyambar pancing jigs beradium di sampingnya. Mungkin hal inilah salah satu yang menyebabkan hasil tangkapan pancing jigs beradium jauh lebih banyak; sehingga pancing jigs berlampu cenderung hanya berfungsi sebagai atraktor jika dioperasikan bersamaan dalam satu perahu.

Gerakan naik turun pancing jigs juga bergantung pada pemberat yang ditambahkan pada bagian depan kepala jigs. Jika terlalu berat, maka pancing jigs menukik vertikal ketika diulur, sehingga tali utama sering terbelit pada kait di bagian ekor jigs, menyebabkan sotong sulit tertangkap. Sebaliknya, jika terlalu ringan, maka pancing jigs relatif melayang dan menunggu lama untuk disentak gerakan naik; dimana gerakan tersebut tidak mirip dengan mangsa sotong.

\section{KESIMPULAN}

Berdasarkan hasil penelitian yang telah dilakukan maka dapat disimpulkan sebagai berikut:

(1) Penggunaan pancing jigs beradium lebih efektif daripada pancing jigsberlampu terhadap hasil tangkapan sotong.

(2) Semua hasil tangkapan terdiri adalah jenis Sepioteuthis lessoniana, dan faktor-faktor lingkungan yang mempengaruhi pengoperasian pancing jigs antara lain arus, gelombang dan angin.

\section{DAFTAR PUSTAKA}

Badrudin dan H. Mubarak. 1998. Sumber daya cumi-cumi. Potensi dan penyebaran sumber daya ikan laut di perairan Indonesia. Komisi Nasional Pengkajian Stok Sumber Daya Ikan Laut, LIPI, Jakarta.

BRKP-DKP dan P3O-LIPI. 2001. Laporan Akhir Pengkajian Stok Ikan di Perairan Indonesia. Pusat Penelitian dan Pengembangan Oseanologi-LIPI, Jakarta.

Hamzah, M.S. 1990. Pengaruh warna cahaya lampu terhadap hasil tangkapan cumi-cumi (Lolinginidae) dengan alat tangkapan "jigs" di Tanjung Nusaniwe, Teluk Ambon.

Hamzah, M.S. dan Sutomo. 1992. Pengamatan beberapa aspek biologi dan distribusi cumi-cumi (Sepioteuthis lessoniana) di perairan Kep. Kai Kecil, Maluku Utara dan sekitarnya. Proseding Seminar Ekologi dan Pesisir I, Puslitbang Oseanologi-LIPI dan ISOI Jakarta: 322-326.

Kurniawan, H. 2011. Pengaruh warna jigs terhadap hasil tangkapan sotong (Sephia sp) di perairan Selat Lembeh. Skripsi. Fakultas perikanan dan Ilmu Kelautan Universitas Sam Ratulangi, Manado.

Rakian, T. 2011. Pengaruh pancing jigs buatan pabrik dan nelayan terhadap hasil tangkapan sotong (Sepia sp.). Skripsi. Fakultas Perikanan dan Ilmu Kelautan, Universitas Sam Ratulangi, Manado. 
Roper, C.F.E., M.J. Sweeney, and C.E. Nauen. 1984. Cephalopods of the World. FAO Species Catalogue of Species Interest to Fisheries. FAO Fish Synopsis No. 125 Vol. 3. FAO.

Saranga, R. 2009. Pengaruh perbedaan warna "jigs" terhadap hasil tangkapan cumi-cumi (Loligo sp.) di perairan Teluk Manado. Universitas Sam Ratulangi, Manado.

Steel, R.G.D. dan J.H. Torrie. 1989. Principles and Procedures of Statistics: A Biometrical Approach. 2nd ed. Mc Graw Hill International Book Company, London.

Sudjana. 1994. Desain dan Analisis Eksperimen. Edisi III. Tarsito, Bandung. 